\title{
FEATURES OF MANAGEMENT AND MODELING OF BUSINESS PROCESSES OF TOURIST ENTERPRISES
}

\author{
Nadiya Bakalo*, PhD (Economics), Associate Professor \\ Viktor Gryshko**, PhD (Economics), Associate Professor \\ National University "Yuri Kondratyuk Poltava Polytechnic» \\ Olena Sushchenko***, Doctor of Sciences (Economics), Professor \\ Simon Kuznets Kharkiv National University of Economics
}

* ORCID 0000-0002-3260-412X
** ORCID 0000-0001-6987-3879
*** ORCID 0000-0002-2645-8015

(C) Bakalo N., 2020.

(C) Gryshko V., 2020.

(C) Sushchenko O., 2020

Стаття отримана редакиією 07.12.2020 p.

The article received by the reduction 07.12.2020.

Introduction. At this stage of economic development, business process management is a rather complex process, because the main purpose of management is to ensure a high level of business process implementation, which is directly reflected in the results of the enterprise. Based on this, there is a need to study such a definition as business process management. Management, as a specific phenomenon, arose with the advent of man, his conscious work. The whole concept of management was formed in the process of division of labor and became a separate independent species. In a broader sense, management is a complex socio-economic process that involves the targeted impact on objects, systems in order to maintain their sustainability or to transfer from one state to another due to changing circumstances.

Review of the recent research and publications sources. Theoretical and practical aspects of management and modeling of business processes of tourism enterprises have been studied by such wellknown domestic and foreign scientists as: D.D. Gurova, G.I. Mikhailichenko, V.M. Mahovka, I.V. Chernysh and others.

Setting objectives. Control is a specific way of interacting between systems, in which one of the systems (the subject of control) influences the other (the object of control) in order to cause the appropriate reaction necessary to adapt to environmental conditions. The purpose of the article is to assess the features of management and modeling of business processes of tourism enterprises.

Basic material and results. In the early twentieth century, the French industrialist Henri Fayol, considered management as a necessity for the leader, said: "To manage - means to anticipate, study the future and establish a program of action; to organize - means to build a double organism of the enterprise: material and social; to dispose - means to put into operation the personnel of the enterprise; to coordinate means to connect and unite, to combine all actions and skills; to control - means to watch that everything happened according to the established rules and the order ".

In the broadest sense, the concept of management is the influence of the subject on the object of management through a system of methods and techniques using a special technology to achieve this goal [1].

The basis of management is the focus on achieving the appropriate goal, identifying ways and means of its implementation, development of a decision-making program for a particular real situation (task), which allows you to control the interaction of all parts and elements of organizational and economic mechanism [2].

Thus, management is the impact on the team that is aimed at achieving the goal, and the necessary interrelated activities; organization, leverage and regulation of this process through feedback; people management, development, decision-making and implementation; the best allocation of resources and purposeful processing of information, etc. All these elements together, in inseparable connection and interaction are components of management. 
The vast majority of scientific approaches claim that the definition of management follows the unity of statements, namely - management is a direct impact on the object. The impact is based on the implementation of a set of measures that ultimately change the state of the object of management. Analyzing the concepts of "management" and "business process", we can come to the logical statement that business process management is a process of applying specific techniques, methods, measures to purposefully influence the functioning of the business process, namely to ensure effective implementation of operations for obtaining a high level of economic benefits. This statement indicates that the focus is on the smooth operation of operations within business processes.

There is a specific of business process management of tourism enterprises that have its own characteristics and features. Issues of theory and methodology of formation of the mechanism of management of such a complex economic area - tourism, remain the subject of scientific research and scientific and practical discussions [3]. Emphasis is placed on the fact that the tourism industry is a nonproductive sphere, the offer of a tourism enterprise consists of a comprehensive list of services that are preformed into a tourism product (Fig. 1).

The main business processes of a tourist enterprise are aimed at creating a tourist product. The process of its modeling and preparation for implementation requires a large number of resources (material, informational, human, financial). Designing a tourism product begins with monitoring the needs of consumers and finding ways to maximize their satisfaction.

Tourism product design covers a significant number of business processes and subprocesses within a single business process. The majority of business processes of a tourist enterprise focus on the search for providers of tourist services (accommodation establishments, transport companies) and the process of forming a tourist product (development of tours).

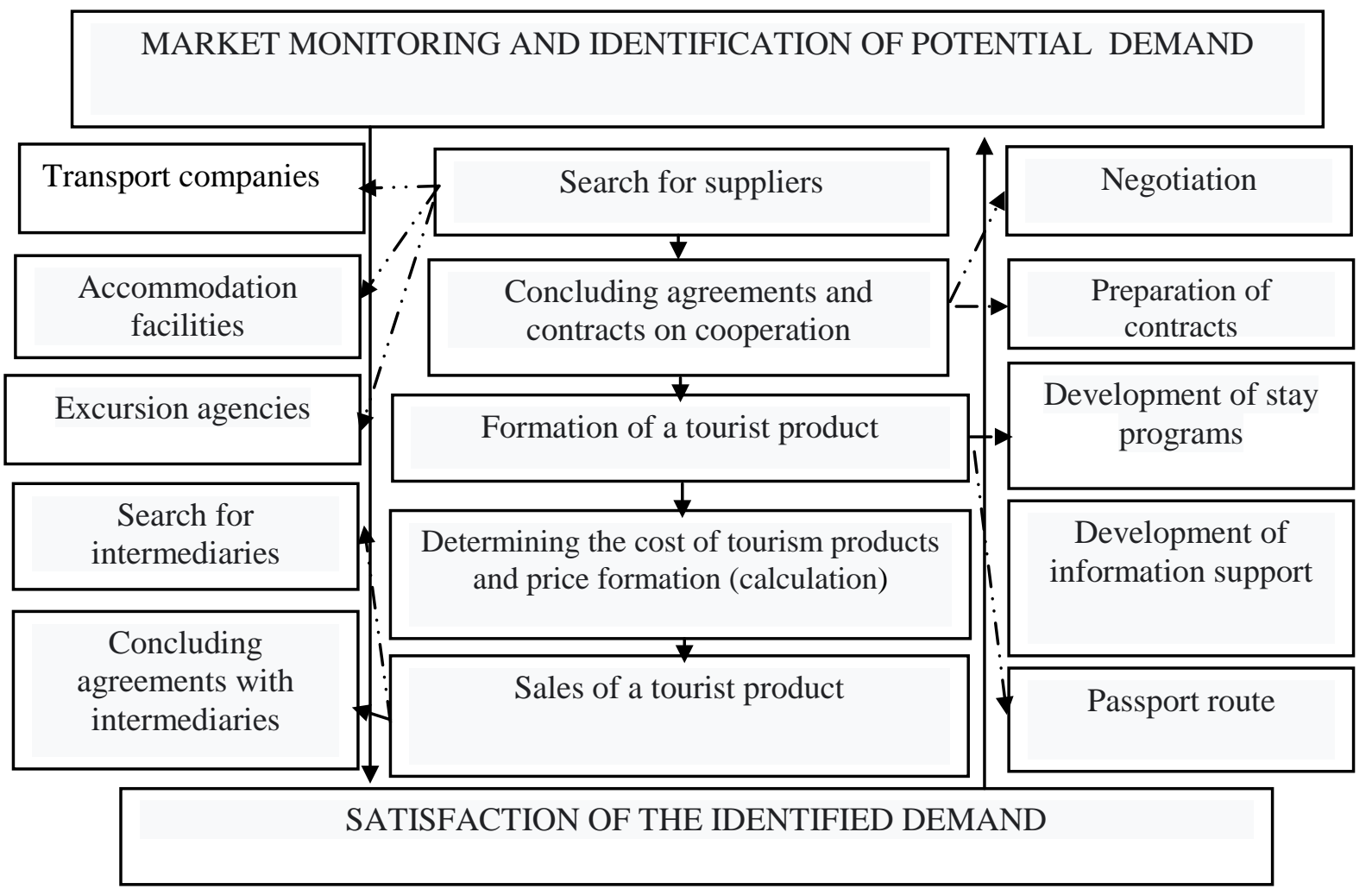

Fig. 1. Implementation of the main business processes of the tourist enterprise (compiled by the author on the basis of [4])

The business process, which is aimed at the sale of a tourist product, distinguishes tourist enterprises into tour operators and travel agents. The task of the tour operator is the formation of the travel product, and the travel agents' is its direct implementation under pre-concluded agreements.

Given the definition of the essence of the business process of a tourist enterprise and the separation of its properties, we can say that the management of business processes of a tourist enterprise is a managerial influence on the process of forming a tourist offer by implementing a set of techniques and measures to ensure effective and efficient business processes full satisfaction of tourist demand. 
On the basis of certain features of realization of business processes of the tourist enterprises it is possible to form the list of the business processes inherent in the tourist enterprise, reflecting its features and distinguishing from set of the enterprises of other spheres.

In the table. 1. the list of the basic business processes of the tourist enterprise is described; just the most important ones are singled out. If necessary, the list of business processes can be changed, they can be removed and added depending on the specifics of the activity and size of the tourist enterprise.

Table 1

List of main business processes of a tourist enterprise [5]

\begin{tabular}{|c|c|c|}
\hline \multicolumn{2}{|c|}{ Business processes } & Subprocesses (actions, operations) \\
\hline \multirow{2}{*}{$\begin{array}{l}\text { Strategy } \\
\text { development }\end{array}$} & $\begin{array}{l}\text { 1.1. Analysis of the } \\
\text { external environment }\end{array}$ & $\begin{array}{l}\text { 1.1.1. Research of the economic situation; } \\
\text { 1.1.2. Monitoring of the regulatory framework; } \\
\text { 1.1.3. Assessment of strengths and weaknesses }\end{array}$ \\
\hline & $\begin{array}{l}\text { 1.2. Defining } \\
\text { development priorities }\end{array}$ & $\begin{array}{l}\text { 1.2.1. Market segment selection; } \\
\text { 1.2.2. Formation of strategic goals; } \\
\text { 1.2.3. Defining the concept of development }\end{array}$ \\
\hline \multirow{2}{*}{$\begin{array}{l}\text { Market analysis } \\
\text { and consumer } \\
\text { needs }\end{array}$} & $\begin{array}{l}2.1 . \quad \text { Determining } \\
\text { consumer needs }\end{array}$ & $\begin{array}{l}\text { 2.1.1. Consumer surveys; } \\
\text { 2.1.2. Focus group analysis }\end{array}$ \\
\hline & 2.2. Market research & $\begin{array}{l}\text { 2.2.1. Monitoring the pricing policy in the market; } \\
\text { 2.2.2. Monitoring the offer of tourist services } \\
\text { 2.2.3. Monitoring the advantages of competitors }\end{array}$ \\
\hline \multirow{4}{*}{$\begin{array}{l}\text { Formation of a } \\
\text { tourist product }\end{array}$} & $\begin{array}{l}\text { 3.1. Concluding } \\
\text { contracts with service } \\
\text { providers }\end{array}$ & $\begin{array}{l}\text { 3.1.1. Negotiating the possibility of providing services; } \\
\text { 3.1.2. Coordination of draft contracts for the supply of } \\
\text { services }\end{array}$ \\
\hline & $\begin{array}{l}\text { 3.2. Formation of tourist } \\
\text { destinations }\end{array}$ & $\begin{array}{l}\text { 3.2.1. Development of tourist routes; } \\
\text { 3.2.2. Development of excursion programs }\end{array}$ \\
\hline & $\begin{array}{l}\text { 3.3.Defining a package } \\
\text { of services }\end{array}$ & $\begin{array}{l}\text { 3.3.1. Development of the list of services; } \\
\text { 3.3.2. Development of service classes }\end{array}$ \\
\hline & $\begin{array}{l}\text { 3.4. Formation of the } \\
\text { value of the tourist } \\
\text { product }\end{array}$ & $\begin{array}{l}\text { 3.4.1. Determining the cost of the product; } \\
\text { 3.4.2. Formation of the final cost of the tourist product; } \\
\text { 3.4.3. Planning discounts and promotional offers }\end{array}$ \\
\hline \multirow{3}{*}{ HR } & 4.1. Recruitment & $\begin{array}{l}\text { 4.1.1. Defining staff qualification requirements; } \\
\text { 4.1.2. Identifying sources of recruitment }\end{array}$ \\
\hline & 4.2. Personnel training & $\begin{array}{l}\text { 4.2.1. Staff training; } \\
\text { 4.2.2. Organization of trainings, seminars }\end{array}$ \\
\hline & 4.3. Staff development & $\begin{array}{l}\text { 4.3.1. Promotion; } \\
\text { 4.3.2. Staff rotation }\end{array}$ \\
\hline \multirow{2}{*}{$\begin{array}{l}\text { Management } \\
\text { financial } \\
\text { information }\end{array}$} & $\begin{array}{l}\text { 5.1. Management } \\
\text { financial resources }\end{array}$ & $\begin{array}{l}\text { 5.1.1. Cost planning; } \\
\text { 5.1.2. Profit planning; } \\
\text { 5.1.3. Financial risk management }\end{array}$ \\
\hline & $\begin{array}{l}\text { 5.2. Management } \\
\text { accounting }\end{array}$ & $\begin{array}{l}\text { 5.2.1. Providing external and internal financial information; } \\
\text { 5.2.2. Implementation of financial and accounting } \\
\text { transactions; } \\
\text { 5.2.3. Formation of financial statements }\end{array}$ \\
\hline \multirow{2}{*}{$\begin{array}{l}\text { Provision of } \\
\text { resources }\end{array}$} & 6.1.Resource planning & $\begin{array}{l}\text { 6.1.1. Search for possible suppliers; } \\
\text { 6.1.2. Estimation of cost of necessary resources; } \\
\text { 6.1.3. Concluding agreements with travel service providers }\end{array}$ \\
\hline & $\begin{array}{ll}6.2 . & \text { Resource } \\
\text { management } & \\
\end{array}$ & $\begin{array}{l}\text { 6.2.1. Allocation of resources; } \\
\text { 6.2.2. Resource optimization }\end{array}$ \\
\hline \multirow{2}{*}{$\begin{array}{l}\text { Monitoring the } \\
\text { effectiveness of } \\
\text { activities }\end{array}$} & $\begin{array}{l}\text { 7.1. Conducting an } \\
\text { internal audit }\end{array}$ & $\begin{array}{l}\text { 7.1.1. Identifying the causes of deviations from the } \\
\text { established optimal parameters; } \\
\text { 7.1.2. Development of measures to eliminate deviations }\end{array}$ \\
\hline & $\begin{array}{l}\text { 7.2. Quality } \\
\text { management of tourist } \\
\text { services }\end{array}$ & $\begin{array}{l}\text { 7.2.1. Evaluation of the quality of the developed tours and } \\
\text { the quality of tourist service; } \\
\text { 7.2.2. Development of quality improvement measures }\end{array}$ \\
\hline
\end{tabular}


It is advisable to divide and refine business processes according to the type of activity of tourism enterprises. That is why the business processes described in table. 1. (except for Unit 3), are similar for both tour operators and travel agents, because it is the process of formation and sale of travel products that distinguishes operators from agents. Consider the main differences in the formation of a tourist product for travel agents, shown in Fig. 2.

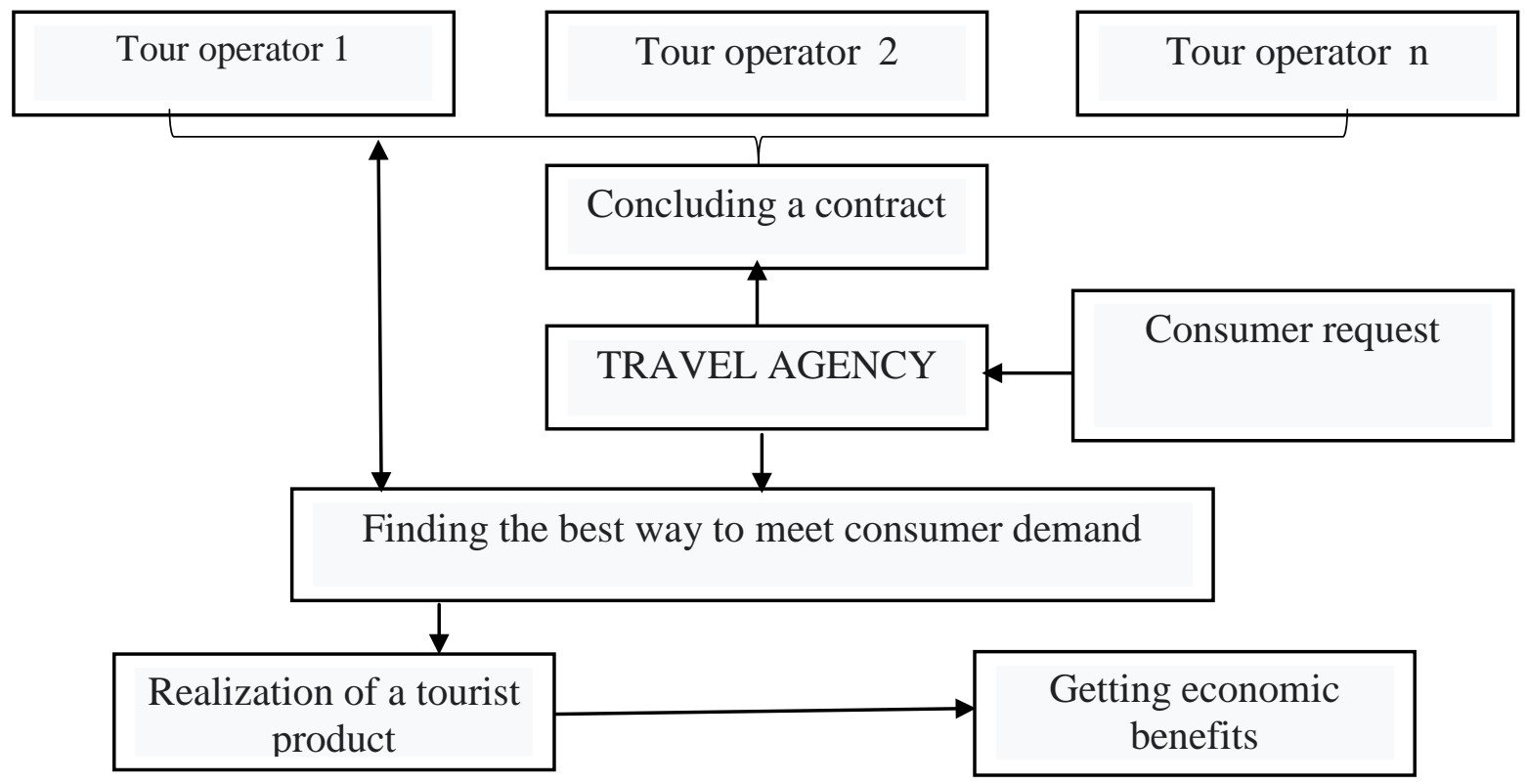

Fig. 2. Implementation of the main business process of travel agencies (compiled by the author on the basis of [6])

Thus, from figure 2 you can see that tour operators are suppliers of products for travel agents. Travel agents, in turn, act as an intermediary between the tour operator and the consumer of services. In this case, the travel agency is a full-fledged enterprise, consisting of an interdependent set of business processes that ensure the smooth operation of this type of enterprise.

Modern theory and practice shows that much attention is paid to the processes and methods (description) of the business process as part of enterprise management technology.

Business process modeling is an important component of business process reengineering projects and the creation of large-scale software systems. The main goals of business process modeling are to transform the model "as is" (as is) into a model "as to be" (as it should be), understanding how the company acts (should act) to achieve its goals.

Several methods are used for business process modeling, the basis of which is a structural and objectively oriented approach to modeling [7]. Consider several methods of modeling business processes that are most suitable for the specifics of the tourist enterprise. The SADT (Structured Analysis and Design Technique) method, developed by D. Ross, is considered a classic method of process approach to management [8].

The main principle of the method is to structure the activities of the enterprise taking into account its business processes and without taking into account the organizational structure. The SADT method is a set of parameters designed to describe the functional model of a business process, in the description of the main operations and their relationship.

According to this principle, the business model is divided into four main levels: Level 1 reflects the interaction of the enterprise with the processes of the external environment; Level 2 describes the main activities of the enterprise and their relationship; Level 3 details business processes, dividing them into elementary operations, grouped by certain characteristics; Level 4 describes the algorithms for performing elementary functions.

The result of applying the SADT method is a model consisting of a list of diagrams represented by individual blocks and text fragments that have interdependent references.

The expediency of using such a method to build a business model of a tourist enterprise is manifested in the possibility of detailing individual business functions, as this principle ensures the orderliness of individual operations and prevents their chaos. 
At this stage, there is a tendency to integrate various methods of business process modeling, one of which is the method ARIS (Architecture of Integrated Information System). ARIS is a methodology, as well as a whole family of software products built on it, developed by IDS Scheer AG (Germany) for structured description, analysis and improvement of business processes, preparation for implementation of complex information systems and controlling business processes. ARIS software products occupy a leading position in the world market in the class of business process modeling and analysis tools.

The ARIS system is a set of tools for analysis and modeling of the enterprise. Its methodological basis is a set of different modeling methods that reflect different aspects of the studied system [8].

The process of modeling business processes covers all aspects of the enterprise, as each process is considered separately, and then creates an integrated model that reflects the relationships between all business processes.

Like the previous one, the ARIS method consists of a set of diagrams, the elements of which are certain blocks that describe specific objects. Each ARIS object has attributes that allow it to detail individual processes. The list of objects is given in table. 2 .

List of ARIS objects [9]

Table 2

\begin{tabular}{|c|c|c|}
\hline № & Object name & Description (purpose) \\
\hline 1 & Function & $\begin{array}{c}\text { Serves to describe the functions (works, procedures) performed by } \\
\text { departments / personnel of the enterprise }\end{array}$ \\
\hline 2 & Event & $\begin{array}{c}\text { Is a description of real events that affect the performance of } \\
\text { functions }\end{array}$ \\
\hline 3 & Organizational unit & $\begin{array}{c}\text { Characterizes the individual organizational units of the enterprise } \\
\text { (management, department) }\end{array}$ \\
\hline 4 & Document & Displays real media \\
\hline 5 & Application system & $\begin{array}{c}\text { Displays a real system that supports and ensures the performance of } \\
\text { functions }\end{array}$ \\
\hline 6 & Information cluster & $\begin{array}{c}\text { Describes the data (set of entities and relationships between them) } \\
\text { used to set the parameters of the model }\end{array}$ \\
\hline 7 & Communication & Describes the type of relationship between objects \\
\hline 8 & Logical operator & $\begin{array}{c}\text { An operator of one of three types ("I", "OR", one that excludes } \\
\text { "OR"), which determines the relationship between events and } \\
\text { functions within the process, allows you to describe the branching } \\
\text { of the process }\end{array}$ \\
\hline
\end{tabular}

Thus, this method allows you to create a business model of the enterprise, which connects the links, which in the usual description are unrelated. The application of the above methods of business process modeling in the activities of tourism enterprises will provide the following benefits:

- clear division of separate business processes into subprocesses with establishment of interrelation between them;

- orderliness of business processes of the tourist enterprise;

- construction of process-oriented activity of the enterprise;

- identification of weak links in the business process and their elimination;

- establishing a logical sequence between operations (functions, procedures, actions) of the business process.

The distribution of responsibilities between executors and the coherence of their performance are important for the efficiency of the business process in its modeling, as the end result depends on the quality of performance of duties by individual executors. This division of responsibilities can be called structuring. The process of structuring business processes is a decomposition or detailing, in the presentation of the elements of the initial level of the model in the following stages by describing their characteristics [10].

One of the main factors in ensuring the effectiveness of such structuring is the distribution of responsibilities between the executors of the process. Each type of work within a particular business process is accompanied by a certain level of complexity and the degree of performance of one type of work directly affects another, because all work within the business process is interdependent. 
To determine the advantages and disadvantages of the business process, a business model is created, which is a formalized (graphical, tabular, textual, symbolic) description of the business process, reflecting the actual or possible end result.

To analyze the business process in practice, complex models are used, which are built on the basis of specialized software. Based on this, it is advisable to make an approach that will describe and analyze the business processes of management staff, which will greatly facilitate the identification and elimination of shortcomings in the implementation of individual business processes (Fig. 3).

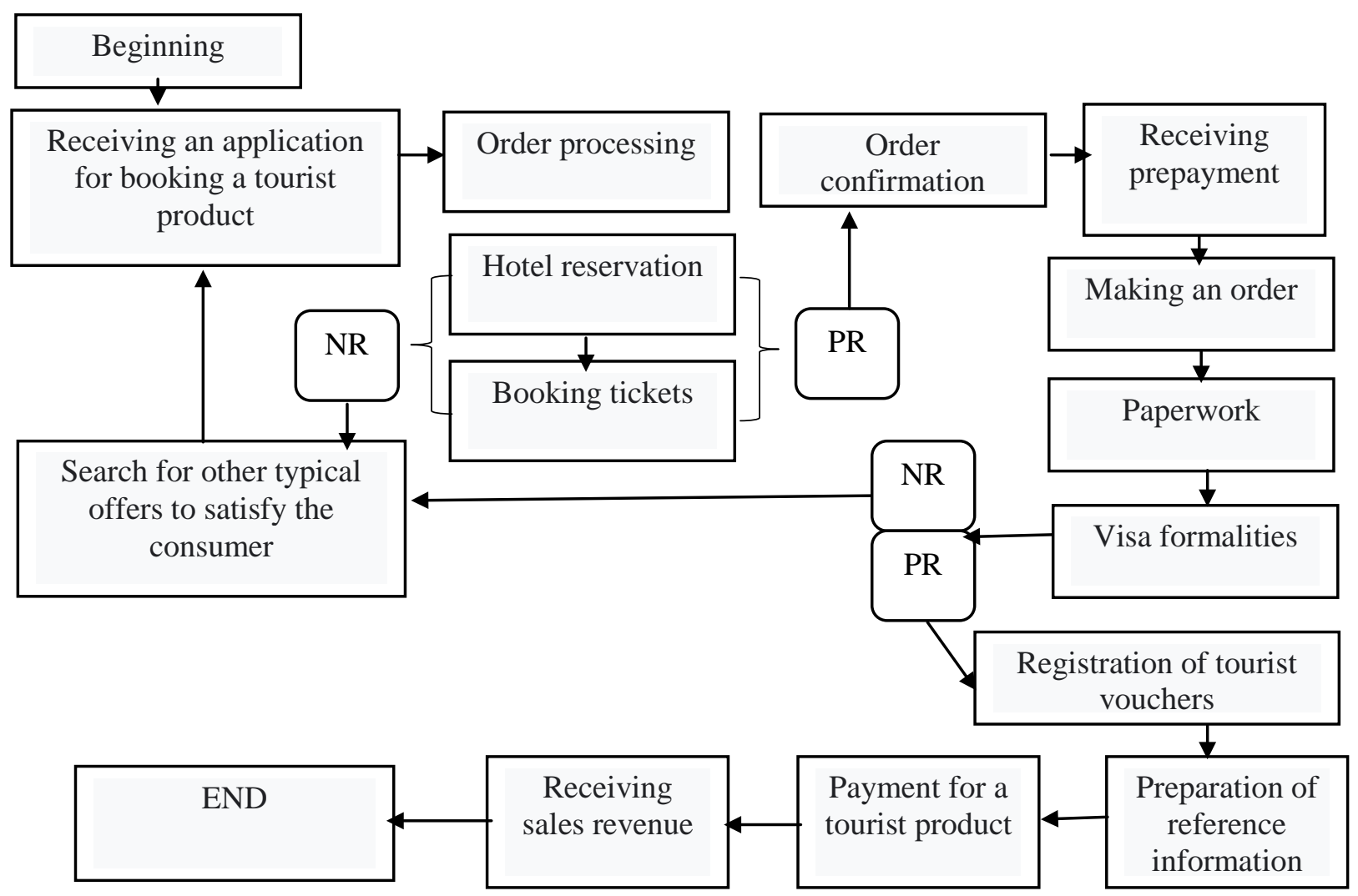

Fig. 3. Structuring of the business process "Realization of a tourist product" (compiled by the author on the basis of [9])

We offer a sequence of business process descriptions:

- setting initial parameters;

- detailing of business processes. Individual transactions, in turn, are a description of the list of transactions that, in general, form a separate business process. This description allows you to determine the necessary resources for the implementation of the business process, which further allows you to minimize excess costs;

- identification of potential shortcomings and ways to solve them (search for alternatives). At this stage, there is a process of identifying and predicting a negative result, the imperfection of the implementation of individual subprocesses, which in turn has an impact on the final indicators;

- structuring. It is based on the construction of a graphic image, because this way of presenting information is easy to perceive;

- analysis of each individual operation and identification of ancillary or priority actions. Helps optimize the business process by eliminating unnecessary procedures;

- formation of the expected end result. Establishing the required level of effect, which will stimulate the search for appropriate ways to implement operations within a particular business process.

Such a description of the business process allows you to carefully consider a set of interdependent subprocesses and identify and prevent the possibility of a negative outcome of a particular subprocess, which will affect the quality and duration of the business process as a whole.

Conclusions. Thus, the described methods of structuring business processes allow analyzing and eliminating negative consequences, contributing to the creation of the necessary prerequisites for the rational and effective functioning of the business processes of a tourist enterprise. 


\section{REFERENCES}

1. Bakalo, N., Strygun, V., Chornomord, O., (2020) Implementation of global Internet technologies in tourism enterprises on the basis of customer-oriented approach. Young scientist. Poltava, Ukraine.

2. Shiryaev, V. and Shiryaev E. (2014). Business process management: Finance and Statistics. Moskov. [in Russian]

3. Roter, M. (2015) Learn to see business processes: Building maps of value creation flows. Alpina Publisher.

4. Mykhailichenko, G. (2012) Information support of innovative touring processes [Tourist business: world tendencies and national priorities: materials VI International scientific practice. conf.] Kharkiv, [in Ukrainian]

5. Melnichenko, S. (2010). Information technologies in tourism: theoretical and practical aspects. Bulletin of Zaporizhia National University, Zaporizhia. 2 (6), 129-138.

6. Falko, E. (2015) Informatization of international tourist business: world trends and macroeconomic aspect. Bulletin of ChSTU. Series: Economic Sciences. Cherkasy, 84-92 [in Ukrainian].

7. Pulina T.V. (2006) Reengineering as a tool for innovation and investment activities of food industry enterprises. Kyiv. Nat. u. food. Technolog. [in Ukrainian].

8. David, A. Mark and Clement McGowan (2004) Methodology of structural analysis and design SADT Foreword by Douglas. Structured Analysis \& Design Technique. [in English].

9. Melnichenko, S. (2008) Automated reservation systems in tourism [Culture of the peoples of the Black Sea region]. 96-100. [in Ukrainian]

10. Chudnovsky, A. (2006) Information management technologies in tourism: a manual [KNORUS]. 104. [in Ukrainian]

11. Gottfried Vossen, Andreas Oberweis, Thomas Karle (2012) "Business Processes for Business Communities: Modeling Languages, Methods, Tools" by Frank Schönthaler. Springer. [in English].

\section{УДК 338.46(477.51)}

JEL Z 32

Бакало Надія Віталіївна, кандидат економічних наук, доцент. Гришко Віктор Володимирович, кандидат економічних наук, доцент. Національний університет «Полтавська політехніка імені Юрія Кондратюка». Сущенко Олена Анатоліївна, доктор економічних наук, професор. Харківський національний економічний університет імені Семена Кузнеця. Особливості управління та моделювання бізнес-процесів туристичних підприсмств. Розглянуто головні бізнес-процеси туристичного підприємства, спрямовані на створення туристичного продукту. Проаналізовано поняття «управління» та «бізнес-процес». З'ясовано, як відбувається реалізація основних бізнес-процесів туристичного підприємства. Визначено сутність бізнес-процесу туристичного підприємства й виокремлено його властивості. Вивчено метод SADT (Structured Analysis and Design Technique), що $є$ сукупністю параметрів, призначених для опису функціональної моделі бізнес-процесу, тобто опису основних операцій та їх взаємозв'язку. Доведено доцільність застосування такого методу для побудови бізнес-моделі туристичного підприємства, яка виявляється у можливості деталізації окремих бізнес-функцій, оскільки цей принцип забезпечує впорядкованість виконання окремих операцій і попереджує їх хаотичність.

Сформульовано перелік бізнес-процесів, притаманних туристичному підприємству, що відображають його особливості й вирізняють із сукупності підприємств інших сфер. Визначено, що переважна частина бізнес-процесів туристичного підприємства зосереджується на пошуку постачальників туристичних послуг (заклади розміщення, транспортні компанії) та процеси формування туристичного продукту (розроблення турів). Розглянуто й сформовано бізнес-модель, яку поділили на чотири основні рівні. Для моделювання бізнес-процесів визначено кілька методів, основою котрих є структурний та об'єктивно орієнтований підхід до моделювання. Важливого значення для забезпечення ефективності бізнес-процесу при його моделюванні набуває розподіл обов'язків між виконавцями й злагодженість їх реалізації, оскільки кінцевий результат залежить від якості виконання обов'язків окремими виконавцями. Структуровано бізнес-процеси реалізації туристичного продукту.

Ключові слова: бізнес-процеси, туристичний продукт, бізнес-модель підприємства, туристичні підприємства, турагенти. 
УДК 005.511:338.48

JEL Z 32

Nadiya Bakalo, PhD in Economics, Associate Professor. Viktor Gryshko, PhD in Economics, Associate Professor. National University «Yuri Kondratyuk Poltava Polytechnic». Olena Sushchenko, Doctor of Sciences (Economics), Professor. Simon Kuznets Kharkiv National University of Economics. Features of Management and Modeling of Business Processes of Tourist Enterprises. The main business processes of a tourist enterprise aimed at creating a tourist product are considered. It is defined the essence of the business process of a tourist enterprise and highlighted its properties. The business model is considered and formed, which is divided into four main levels. Several methods have been identified for business process modeling, based on a structured and objectively oriented approach to modeling. The business processes of tourist product realization are structured.

Key words: business processes, tourist product, business model of enterprise, tourist enterprises, travel agents. 